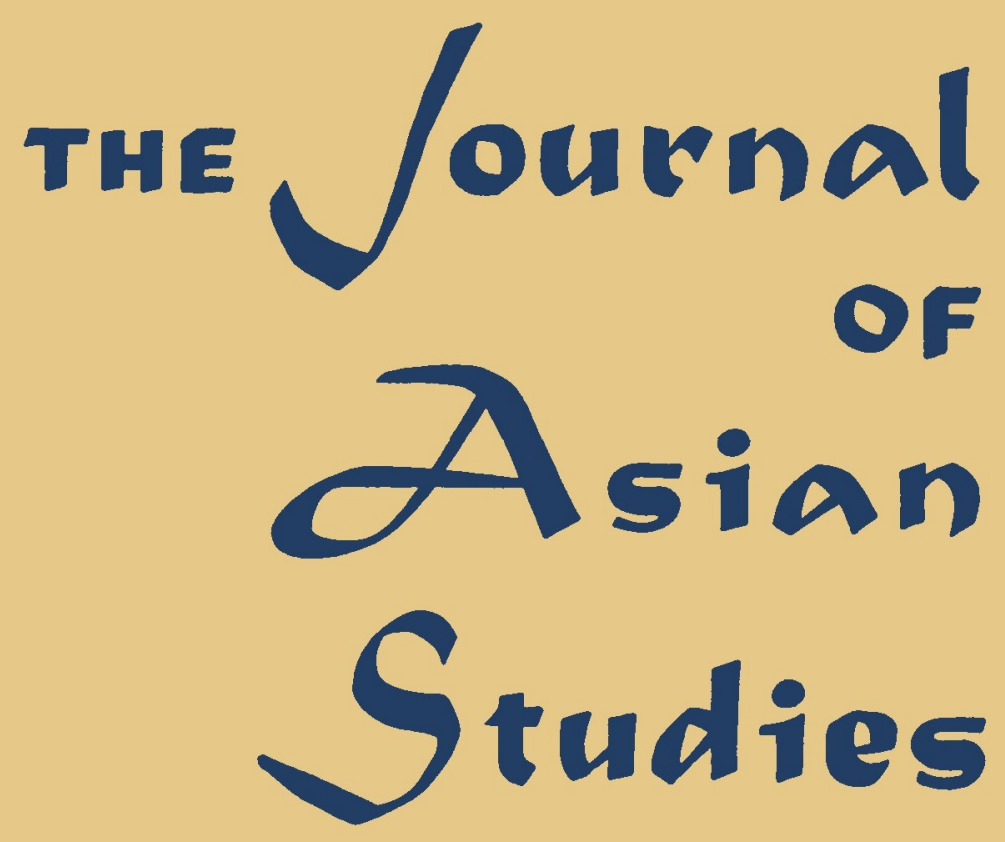

PUBLISHED BY THE ASSOCIATION FOR ASIAN STUDIES, INC.

\title{
Volume XXXII, Number 4
} August 1973 


\section{THE JOURNAL OF ASIAN STUDIES \\ Formerly the Far Eastern Quarterly}

H. D. Harootunian, Editor

University of Chicago
Robert B. Hall, Jr., Associate Editor

University of Rochester

Helen McCready-Kearney, Editorial Assistant

University of Rocbester

Southeast Asia

JOHN K. WhiTMORE

University of Micbigan

JAMES L. PEACOCK

University of Nortb Carolina

Cbina

Ralph C. Croizier

University of Rochester

Michel Oksenberg

Columbia University

Charlotte Furth

California State University

Long Beach

Soutbeast Asia

Aram Yengoyan

University of Michigan

Clsina

Jonathan D. Spence

Yale University
BOARD OF ASSISTANT EDITORS

Japan

Tetsuo Najtra

University of Chicago

RoBeret J. SMith

Cornell University

Sonth Asia

Pauline Kolenda

University of Houston

Joseph T. O'ConNell

University of Toronto

JoHN RicharDS

University of Wisconsin, Madison

SUSAN HadDEN

Oakland University

BOOK REVIEW EDITORS

Japan

Bernard S. Silberman

Duke University

Korea

Peter H. Lee

University of Harwaii

Soutb Asia

J. Michael Mahar

University of Arizone

\section{THE ASSOCIATION FOR ASIAN STUDIES, INC.}

OFFICERS OF THE ASSOCIATION

George McT, Kahin, President

Cornell University

Richard L. Park, Secretary-Treasurer University of Michigan

Richard D. Lambert, Vice-President

University of Pennsylvania

Rhoads Murphey, Chairman Publications Committee University of Micligan

Robert E. Ward, Past President Stanford University

Ardath W. Burks (1972-75)

Rutgers University

Peter Duus-At Large Member (1972-75) Stanford University

L. A. Peter Gosling (1972-75) University of Michigan

Hugh H. W. KaNG (1971-74)

University of Hawaii

K. C. Liv-At Large Member (1971-74) University of California, Davis

Rhoads Murphey-At Large Member (1973-76) University of Micbigan

Kusum NaIR (1973-76) East-West Center

Carol Jean Johnson Administrative Assistant
BOARD OF DIRECTORS

Michel OKsenberg ( $1971-74)$ Columbia University

Karl H. Potter ( $1971-74)$ University of Washington

Barbara Ruch (1973-76) University of Pennsylvania

SusanNe H. Rudolph (1972-75) University of Chicago

Tang Tsou (1973-76) University of Chicago

WeI-MING Tu (1972-75) University of California, Berkeley

WaLter F. VelLa (1971-74) University of Hawaii

David O. D. Wurfel $(1973-76)$ University of Windsor

Victoria G. SPANG Comptroller 


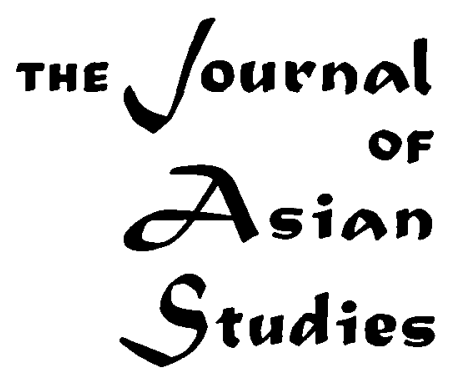

Vol. XXXII, No. 4

August 1973

\section{CONTENTS}

\section{ARTICLES}

579 The Mindful Peasant: Sketches for a Study of Rebellion IRWIN SCHEINER

593 The Solitary Boat: Images of Self in Chinese Nature Poetry EUGENE EOYANG

“HOW MUCH TRUTH CAN A BLADE OF GRASS CARRY?": Ch'en Ying-chen and the Emergence of Native Taiwanese Writers JOSEPH S. M. LAU

639 Death in India, 1871-1921

$$
\text { IRA KLEIN }
$$

661

COMMUNICATIONS

\section{REVIEW ARTICLES}

663 Zen and the West, Revisited LEON HURVITZ

669 Theories Concerning the Skandhaka: An Appraisal CHARLES S. PREBISH

679 New Perspectives on American-East Asian Relations WALTER LAFEBER

\section{BOOK REVIEWS}

Asia General

EASt, SPate AND Fisher, (eds.), The Changing Map of Asia, A Political Geography

China

684 MACKerRas, The Rise of the Peking Opera, 1770-1870: Social Aspects of the Theatre in Manchu China

Articles in the Journal of Asian Studies represent neither the views of the Association for Asian Studies nor those of the Editors. The Editor is responsible for the final selection of the content of the Journal and reserves the right to reject any material deemed inappropriate for publication. Responsibility for opinions expressed and for the accuracy of facts published in articles rests solely with the individual authors. Copyright (C) 1973 by THE Association for Asian Studies, Inc.

Requests for permission to reprint should be directed to the Editor. The Journal is indexed in the Social Sciences \& Humanities Index and Book Reviez Index and abstracted in Historical Abstracts and America: History and Life. It is also available on film through University Microfilms, Ann Arbor, Michigan 48104. 
687 NIEH, Shen Ts'ung-wen

689 Ferguson, China Medical Board and Peking Union Medical College. A Chronicle of Fruitful Collaboration, 1914-1951 MARY BRowN BULLOck

689 Bowers, Western Medicine in a Chinese Palace. Peking Union Medical College, 1917-1951

MARY BROWN BULLOCK

691 KARnow, Mao and China: From Revolution to Revolution

JAMES C. HSIUNG

693 scalapino, Elites in the People's Republic of China

JEROME CH'EN

693 ғоккемА, Report from Peking: Observations of a Western Diplomat on the Cultural Revolution

JEROME CH'EN

693 CHEN, New Earth

JEROME CH'EN

693 Hsiao, Chinese Communism in 1927: City vs Countryside JEROME CH'EN

693 KWEI, The Kuomingtang-Communist Struggle in China 1922-1949 JEROME CH'EN

693 Hakrison, The Long March to Power: A History of the Chinese Communist Party

JEROME CH'EN

696 FITZGERALD, China and the Overseas Chinese

GRAHAM E. JOHNSON

699 Larkin, China and Africa 1949-1970. The Foreign Policy of the People's Republic of China

GEORGE T. YU

699 mejuen, Marriage Law and Policy in the Chinese People's Republic

DAVID C. BUXBAUM

701 moseley, The Consolidation of the South China Frontier

KENT C. SMITH

702 brodine and Selden, (eds.), Open Secret. The Nixon-Kissinger Doctrine in Asia

JOHN H. FINCHER

Japan

704 LARGE, The Yuaikai, 1912-1919: The Rise of Labor in Japan

KOZO YAMAMURA

705 sмiтн, Japan's First Student Radicals

KENNETH B. PYLE

706 YU, Akutagawa: An Introduction

YOSHIO IWAMOTO

707 conroy and miyaknwa, (eds.), East Across the Pacific: Historical and Sociological Studies of Japanese Immigration and Assimilation

ROBERT J. SMITH

708 Minear, Victor's Justice: The Tokyo War Crimes Trial

KURT STEINER

709 aXelbank, Black Star Over Japan: Rising Forces of Militarism

ALvin D. $\operatorname{coox}$

711 hellmann, Japan and East Asia: The New International Order

JAMES W, WHITE South Asia

712 coнn, India: The Social Anthropology of a Civilization

J. H. BROOMFIELD

713 Callahan, The East India Company and Army Reform, 1783-1798

STEPHEN P. COHEN

714 PRICHARD, The Chronicles of Budgepore or Sketches of Life in Upper Indio

TOM G. KESSINGER

714 монаммар, (comp. and ed.), Writings and Speeches of Sir Syed Ahmad Khan

MARGARET H. CASE

715 Azız, (comp. and ed.), The All India Muslim Conference 1928-1935: A Documentary Record

MATTISON MINES 
715 mathur, Muslims and Changing India

MATTISON MINES

716 Gноsн, The Disinherited State: A Study of West Bengal 1967-1970

716 Bangla Desh Documents. Ministry of External Affairs

BARRIE M. MORRISON

716 chopra, (ed.), The Challenge of Bangla Desh: A Special Debate

BARRIE M. MORRISON

BARRIE M. MORRISON

716 MORAEs, The Tempest within: An Account of East Pakistan

BARRIE M. MORRISON

720 NaIK, India, Russia, China and Bangla Desh

CHARLES H. ASHTON

GAIL MINAULT

721 Brown, Gandhi's Rise to Power: Indian Politics 1915-1922

PHILIP OLDENBURG;

722 KAYE, Communism in India

722 seshadri and Jain, Panchayati Raj and Political Perceptions of Electorate: A Study of Electoral Behavior in the Mid-Term Poll of 1971 in Hyderabad Constituency BRIAN wilson coyer

723 Caplan, Priests and Cobblers: A Study of Social Change in a Hindu Village in Western Nepal

JAMES F. FISHER

724 Chand, Population in Perspective: A Study of Population Crisis in India in the Concext of New Social Horizons

S. CHANDRASEKHAR

724 dandekar and bhate, Prospects of Population Control: Evaluation of Contraception Activity (1951-1964)

S. CHANDRASEKHAR

725 Pattanayak, Aspects of Applied Linquistics

JAMES M. LINDHOLM

726 roadarmel, (ed. and trans.), $A$ Death in Delhi

CARLo COPPOLA

727 SAHGal, The Day in Shadow

MARCARET E. DERRETT

728 coldstein, Indian Women in Transition: A Bangalore Case Study

AILEEN D. ROSS

728 vatuk, Kinship and Urbanization: White Collar Migrants in North India

AILEEN D. ROSS

Southeast Asia

729 Tate, The Making of Modern South-East Asia. Volume One. The European Conquest

JOHN R. W, SMAIL

731 waddel, An Introduction to Southeast Asian Politics

DAVID A. WILSON

731 Southeast Asia's Economy in the 1970's. (Asian Development Bank)

FRANK H. COLAY

734 Carroll, (ed.), Adoption in Eastern Oceania

ROBERT MCKINLEY

737 WERTHEIM, Buiten de grenzen: sociologische opstellingen aangeboden aan prof

WILLIAM H. FREDERICK

738 Kesavan, Japan's Relations with Southeast Asia: 1952-60. With Particular Reference to the Philippines and Indonesia

MASAHI NISHIHARA

740 stewant, The Pagoda War: Lord Dufferin and the Fall of the Kingdom of Ava, 1885-6

oliver B. POLLAK

741 maran, Burmese and Jingpho: A Study of Tonal Linguistic Processes

JAMES A. MATISOFF

743 Aнmad, Economic Resources of the Union of Burma

ROBERT E. HUKE

744 Wyatr, The Politics of Reform in Thailand: Education in the Reign of King Chulalongkorn

WALTER F, VELLA 
745 sweeney, Malay Shadow Puppets: The Wayang Siam of Kelantan

746 Kanapathy, The Malaysian Economy: Problems and Prospects

WILLIAM P. MALM

746 HARRISSON AND Harrisson, The Prehistory of Sabah

GAYL D. NESS

748

749 DE MEneses, The Conquest of Malacca

WILHELM G. SOLHEIM II

J. G. CASParis PaNG, Singapore's People's Action Party; Its History, Organization and Leadership

GAYL D. NESS CHan, Singapore: The Politics of Survival, 1965-1967

GAYL D. NESS Lecce, Sukarno: A Political Biography

STEPHEN SLOAN ReINhaRd, Foreign Policy and National Integration: The Case of Indonesia

bernas, A Historical and Juridical Study of the Philippine Bill of Rights

SHORTER NOTICES

COLLECTED ABSTRACTS (VOLUME (XXXII)

\section{ANNUAL INDEX}

The Journal of Asian Studies, known until September 1956 as the Far Eastern Quarterly, is published by The Association for Asian Studies (formerly The Far Eastern Association) in November, February, May, and August. The annual institutional subscription rate is $\$ 30.00$, postage included. Subscribers also receive the annual Bibliography and semiannual Professional Revicz. Single issues of the Journal and Bibliography, beginning with the May 1965 issue cost $\$ 8.00$ plus postage and can be ordered from the Secretariat. Earlier beginning with the May 1965 issue. cost $\$ 8.00$ plus postage and can be ordered from the Secre
issues may be purchased from A.M.S. Reprints, 56 E. 13th Street, New York, New York 10003 .

Annual membership dues are $\$ 20.00$ ( $\$ 10.00$ for full-time students) payable April 1. Regular and student members receive the Journal of Asian Studies, the annual Bibliography of Asian Sttudies, the semiannual Asian Studics Professional Review, and the Asian Studies Newsletter. Second.class postage paid at Ann Arbor, Michigan and at Richmond, Virginia.

Individual and back issues of the Journal and Bibliography to the membership cost $\$ 6.00$ plus postage for regular members, and $\$ 4.00$ plus postage for student members. All correspondence regarding membership, subscriptions, advertising, or business should be addressed to the Secretary or Business Manager, Association for Asian Studies, Inc., Room 1, Lane Hall, University of Michigan, Ann Arbor, Michigan 48104.

Manuscripts for publication and correspondence concerning articles should be submitted to Professor H. D. Harootunian, Editor, Journal of Asian Studies, University of Chicago, Gates-Blake, 5811 South Ellis, Chicago, Illinois 60637. Original Manuscripts are to be typed on $81 / 2 \times 11$ bond, double spaced, and must not exceed about 35 pages in length; they should be accompanied by two clear copies.

Correspondence concerning books for review and book reviews should be sent to the appropriate editors: Professor Bernard S. Silberman, Department of History, Duke University, Durham, North Carolina 27706 , Review Editor (Japan and Northeast Asia); Professor Aram Yengoyan, Department of Anthropology, 23 Angell Hall, University of Michigan, Ann Arbor, Michigan 48104, Review Editor (Southeast Asia); Professor Jonathan Spence, History Department, Yale University, New Haven, Connecticut 06520, Review Editor (China and Inner Asia); Professor J. Michael Mahar, Department of Oriental Studies, University of Arizona, Tucson, Arizona 85721, Review Editor (South Asia). Professor Peter H. Lee, Department of East Asian Literature, University of Hawaii, Honolulu, Hawaii 96822, Review Editor (Korea). 